SVU- International Journal of Veterinary Sciences, 1 (2): 50-59, 2018.

\title{
Complete Cervico-vaginal Prolapse (CVP) in a Ewe
}

\section{Ahmed SA Hassaneen*}

Department of Theriogenology, Obstetrics and Artificial Insemination, Faculty of Veterinary Medicine, South Valley University 83523, Qena, Egypt

\section{Abstract}

A four-years-old pluriparours (parity; $n=2$ ) pregnant Kanze/Dershawy ewe, of a body weight about $40 \mathrm{~kg}$ at Halayeb city, Red Sea province, Egypt was presented with a history of restlessness, straining, and appearance of a permanent/complete cervico-vaginal prolapse as a smooth, red, and rounded mass at the rear end of the ewe. There was no history of previous cervico-vaginal prolapse during or after previous pregnancies. Complete procedures of the appropriate successful treatment were described in this study. Briefly, treatment was performed under caudal epidural analgesia; the prolapsed mass was immediately covered with a towel soaked in water, examined for presence of injuries/rupture, raised to evacuate the urinary bladder, replaced by manual fist pressure and by the flat of hands, and finally retention suture was used to prevent the possible reoccurrence. The suture material had been removed before lambing, and the owner was advised to cull the ewe or at least excluded from further breeding.

Keywords:

Epidural anaesthesia, Sheep infertility, Small ruminants, Vaginal prolapse

Received: October 28, $2018 \quad$ Accepted: November 4, $2018 \quad$ Published: November 5, 2018 *Corresponding Author:Ahmed SA Hassaneen E-mail: ahmed.hassaneen@vet.svu.edu.eg Citation: Hassaneen, Complete Cervico-vaginal Prolapse (CVP) in a Ewe. SVU-IJVS 2018, 1 (2): 50-59.

Copyright: (C) Hassaneen. This is an open access article distributed under the terms of the creative common attribution license, which permits unrestricted use, distribution and reproduction in any medium provided the original author and source are created.

Competing interest: The authors have declared that no competing interest exists. 


\section{Introduction}

Vaginal prolapse can be defined as an eversion and pushing of apart or the whole of the vaginal wall with/or without the cervix outside the female body through the vulva (Fielden 1980). Vaginal prolapse is a problem that affecting female of several animal species (Couri et al., 2012) including cows, buffaloes (Dhillon et al., 2006, Miesner and Anderson, 2008, Zacharin, 1969), sheep (Low and Sutherland, 1987, Scott and Gessert, 1998, Sobiraj, 1990), goats (Kamalakar et al., 2017), horses (Riera et al., 1989), donkeys (Onyango et al., 2009), camels (Gitao and Akabwai, 1989), pigs (Bristol and Djurickovic, 1971, Noakes et al., 2009), dogs (Alan et al., 2007, Gouletsou et al., 2009, Singla et al., 2016, SchaefersOkkens, 2001), cats (McKelvey, 2015), and rabbits (Van et al., 1989). Vaginal prolapse is most frequently affecting sheep mainly during their late pregnancy period (McLean, 1956). Although vaginal prolapse occurs mainly in pregnant cows and ewes, it can be also seen in non-pregnant ones (Kahn, 2005). Amongst animal species, vaginal prolapse is seen most frequently in antepartum sheep (Sobiraj, 1990). The incidence of vaginal prolapse in ewe is about $1 \%$ with variation among sheep flocks and annual variations within the individual flocks without clear explanation. Individual farms occasionally have high incidence rate up to $10 \%$ of ewes (Jackson, 2014, Knottenbelt, 1989, Low and Sutherland, 1987).

The term prolapse is derived from the Latin one "prolapi" which means "to fall before" (Watts, 1954). Prolapse is generally defined as the slipping of a body part from its usual position in relation to other parts, according to The Webster's New International Dictionary (2000). Amongst farmers, prepartum vaginal prolapse is known by a wide variety of colloquial terms such as "throwing the reed", "pushed the weather", "popped the rose", "red bag", "split the slit", "bearing disease", and "Rosie" (Edgar, 1952, Knottenbelt, 1989). Local Egyptian farmers and owners call the disorder as "El-Garn" in colloquial Arabic which means "appearance of the horn". Knowing such non-scientific terms/names used by local farmers is important for veterinarians and obstetricians.

The vaginal prolapse sometimes extends up to and includes the cervix. Prolapse of the cervix as a result of vaginal displacement is considered as an extension of a pre-existing vaginal prolapse (Cox, 1987). It is more appropriate to refer such condition as cervico-vaginal prolapse (CVP). Cervico-vaginal prolapse appears as a smooth pink to red mass at the rear end of the ewe. In fresh stage, the incomplete CVP may temporary appears when the ewe is lying down due to increase the intraabdominal pressure, but disappear when the ewe stands. On the other hand, complete CVP does not disappear when the ewe is standing and known as complete CVP. The CVP mass varies in its size from a tennis ball to a melon (Fisher, 2016). Shortly after its permanent displacement, the CVP starts to swell, becomes darker in colour; when the treatment is delayed, the CVP remains displaced for a prolonged period of time and the CVP will start to become dry, easyto-damage and its colour will turned purple/black due to impairment of the blood flow that causing tissue death (Fisher, 2016). Irritability and discomfort due to the displacement of the vagina with/without the cervix progressively leads to increased straining and increases the size of the extensive prolapse (Kahn, 2005). The size of the CVP is also increased and become more swollen due to both the oedema and the urine retention inside the occluded urinary bladder (Kennedy, 2013). 
The pathophysiological origin of the pelvic organs' prolapses including CVP is multifactorial and includes hereditary predisposition, atypical/abnormal connective tissue in the perineal region, hormonal and many other risk factors (Adams, 1990, Couri et al., 2012, Kahn, 2005, Sobiraj, 1990). A previous study on pregnant ewes suffering from CVP reported that ewes with prepartum CVP have high levels of circulating oestrogens in blood (Sobiraj, 1990). These hormonal changes that occur during the last trimester of pregnancy cause a relaxation of the sacroischiatic and sacroiliac pelvic ligaments and the surrounding soft tissues (Wolfe, 2009). The consequent relaxation accompanied with the increased intraabdominal pressure caused by the weight of the gravid uterus, is considered as the most important pre-disposing factor for CVP (Kahn, 2005). Other factors may be contributed in the occurrence of CVP due to increasing the intra-abdominal pressure such as accumulation of intra-abdominal and perineal fat, distention of the rumen, and the hilly grazing areas (Drost, 2007). Other studies reported that hypocalcemia and other dietary and/or metabolic factors such as the grazing on phytoestrogens-richpastures are also contributed in the occurrence of CVP (Adams, 1990, Miesner and Anderson, 2008, Sobiraj, 1990).

Complications as consequences of the CVP include difficult urination, hardening of the CVP wall, occasionally rupture of vaginal wall through which certain organs such as intestine, urinary bladder and/or uterus may eviscerate. All these complications may result in death of the animal. If the ewe survives until lambing without treatment, maternal dystocia is a common sequela (Kennedy, 2013, Kloss et al., 2002, Praveen, 2016, Sobiraj, 1990, Veeraiah and Srinivas, 2010).

In the field conditions, each individual case of CVP is unique and should be approached and treated with a special consideration to its circumstances (Anya et al., 2006, Kumar et al., 2018). There is a plethora of alternative methods for the treatment of CVP in ewes (Hosie, 1993, Lakde et al., 2014, Makhdoomi et al., 2010). The aims of this study were to fully report both the signs, and the treatment of a complete prepartum CVP in a Kanze/Dershawy ewe reared in desert area and provide a review about the CVP and the different alternative methods used for its treatment.

\section{Case Report}

This study was according to the Animal Ethics Committee of the South Valley University for Veterinary Research, Qena, Egypt. A four-years-old pluriparours (parity; $n=2$ ) pregnant Kanze/Dershawy ewe, and of a body weight about $40 \mathrm{~kg}$ at Halayeb city, Red Sea province, Egypt was presented with a history of restlessness, straining, and appearance of a permanent/complete prolapsed mass at the rear end of the ewe. There was no history of CVP during or after the previous pregnancies. The affected ewe was apparently healthy. Clinically, a nearlyrounded, sand-soiled and oedematous cervico-vaginal prolapsed mass appeared at the rear end of the ewe (Fig. 1A, 1B). The diameter of the CVP was $10.5 \mathrm{~cm}$. The CVP was covered with a layer of sands that completely adhered to the mucous membrane of the prolapsed mass; this sandy layer was likely acting as a protective layer for the CVP against possible injuries/tearing. 


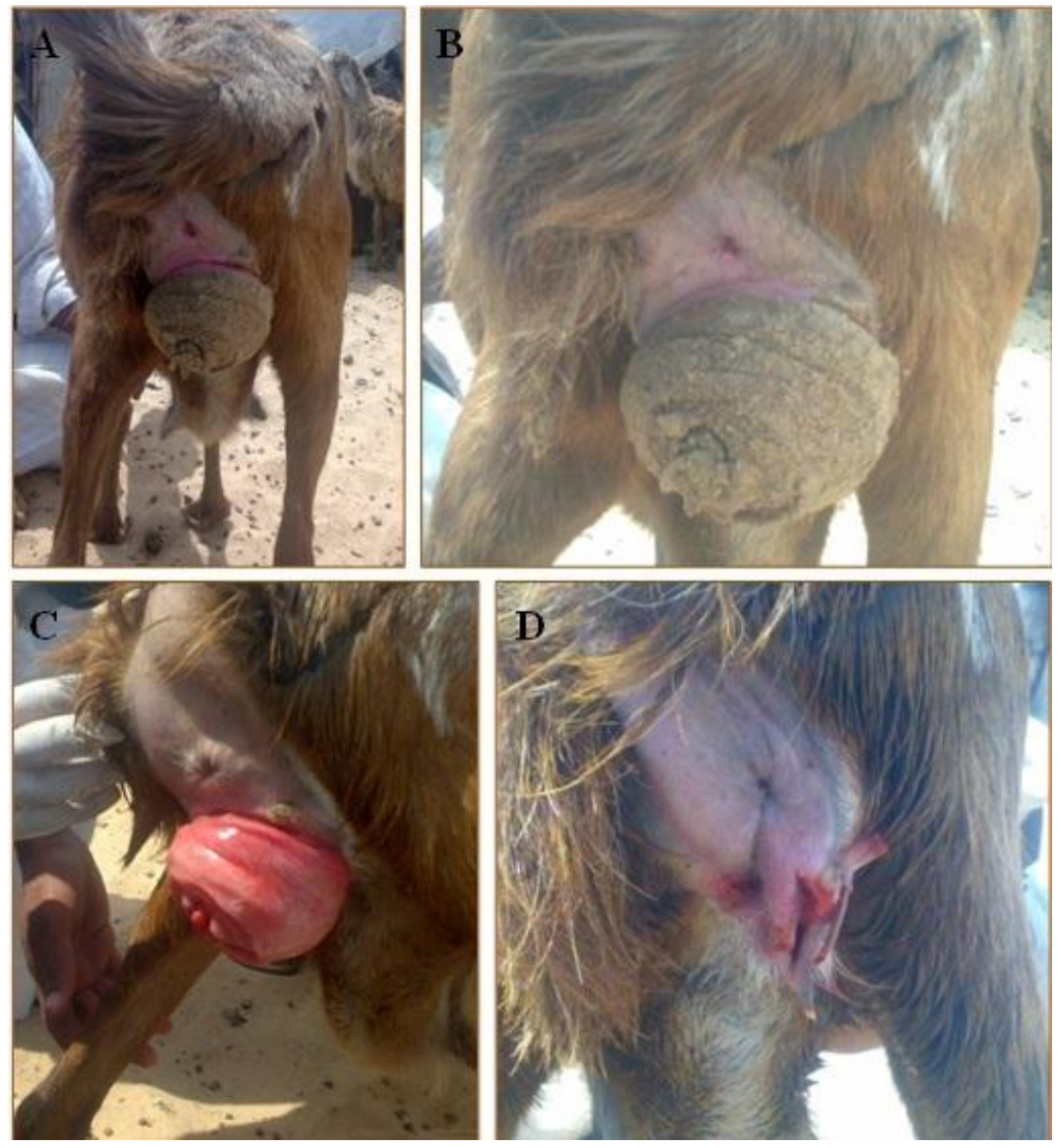

Fig. 1. Prepartum complete cervico-vaginal prolapse in a ewe. (A) A photograph showing a contaminated cervico-vaginal prolapsed mass with a sandy attached layer. (B) A photograph showing a closer view of the prolapsed part. (C) A photograph showing the prolapsed part after being carefully washed, and cleaned before replacement. (D) A photograph showing the vulvar lips after replacement and suturing used to prevent the reoccurrence. Note: The retention suture was removed before lambing.

\section{Treatment}

For successful treatment of the CVP in this Kanze/Dershawy ewe, the prolapsed mass was immediately and completely covered with a towel soaked in water of suitable temperature, and the towel was maintained moisted for about $10 \mathrm{~min}$. to moist the sandy layer and to protect from any further injury/damage, as well. Later on, the towel was removed and plenty water directly poured on the prolapsed mass with gentle washing to remove the sandy layer and any other debris (Fig. 1C). In order to reduce the size of the oedematous CVP, tannic acid 2\% (Al-Nasr Pharmaceutical Company, Egypt) was locally applied for its astringent effect. Caudal epidural analgesia was performed by administration of $2 \mathrm{ml}$ of a local anaesthetic solution; lidocainehydrochloride $0.5 \mathrm{mg} / \mathrm{kg}$ (Debocaine $2 \%$, The Arab Company for Gelatin and Pharmaceutical Products for Al-Debeiky Pharmaceutical Industries, Industrial zone, Obour city, Egypt) into the sacro-coccygeal space (Fig. 2). Caudal epidural analgesia as a safe appropriate analgesia helps the easy replacement of the CVP, suturing of the vulvar lips, and prevention of the reoccurrence (Scott et al., 1995, Scott, 
1996, Zayed et al., Unpublished data). Before replacement, the CVP was carefully checked for presence of wounds or injuries, and then the CVP mass was gently lifted up thereby reducing the fold in the neck of the urinary bladder to allow it passing the accumulated urine which resulted in a more reduction in the size of the CVP. As an essential step to facilitate the replacement, lubrication of the CVP mass using paraffin oil (Sigma-Aldrich Pharmaceutical Industries, Egypt) is applied, followed by careful replacement of the CVP using the fist and the flat of the author hands without forced pushing while the ewe was straining. After replacement, the skin of the vulvar lips was sutured using U-shape horizontal mattress suture about $2 \mathrm{~cm}$ deep from the edges of the vulvar lips (Fig. 1D, and Fig. 3) (Straiton, 1992). The ewe had been administered a single injection of oxytetracycline dihydrate (Alamycin LA 20 $\mathrm{mg} / \mathrm{kg}$; Norbrook Laboratories Limited, Station Worker, Newry, Northern Ireland, United Kingdom) as a broad-spectrum long-acting antibiotic to avoid and reduce the infection, and subjected to flunixin meglumine injection (Flunixin $1.1 \mathrm{mg} / \mathrm{kg}$; Norbrook Laboratories Limited, Station Worker, Newry, Northern Ireland, United Kingdom) as a non-steroidal antiinflammatory, analgesic and antipyretic.

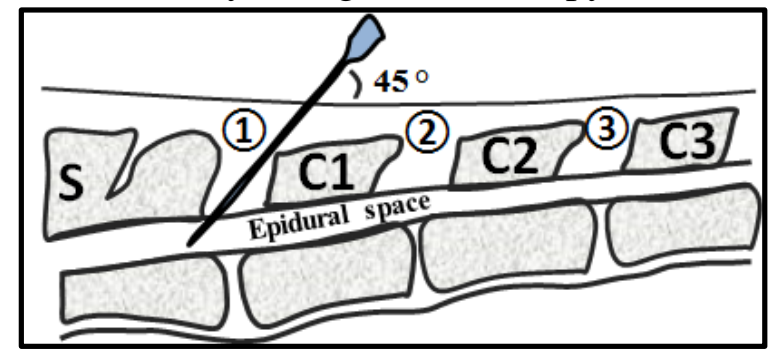

Fig. 2. A schematic diagram of the caudal epidural analgesia injection site in ewe. The schematic diagram is showing the site of injection for caudal epidural analgesia in ewe at the sacro-coccygeal space between the sacrum (S) and first caudal vertebrae (C1). Note: the needle is inserted in an oblique direction with an acute angle of 45 .(1): sacro-coccygeal space, (2): first inter-coccygeal space, (3): second intercoccygeal space, $\mathrm{C} 1$ : first caudal vertebrae, C2: second caudal vertebrae, S: Sacrum.

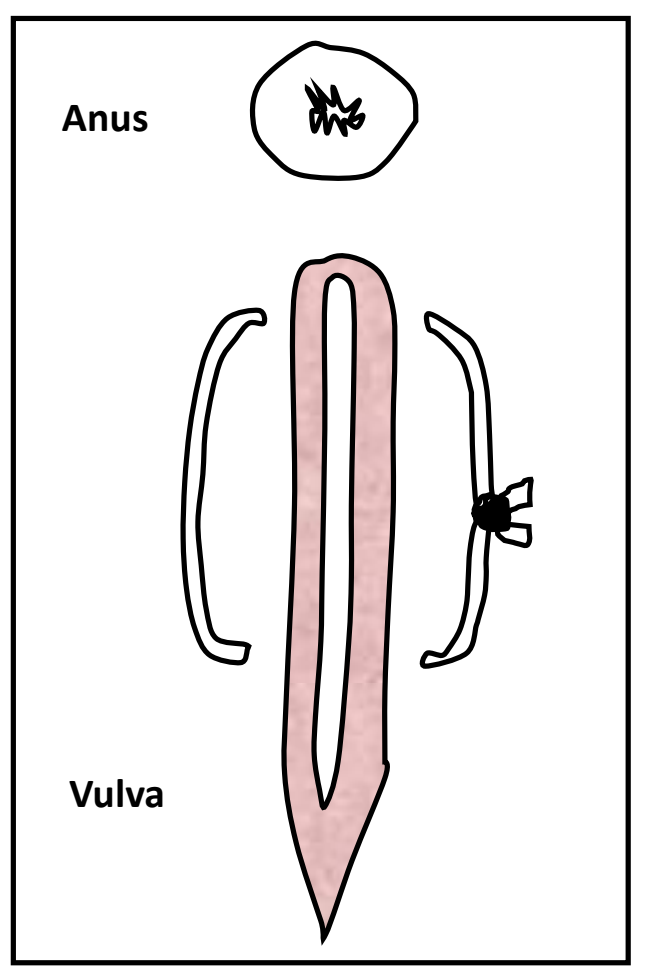

Fig. 3. A schematic diagram of the type of retention suture used to prevent reoccurrence of the prolapse in this study. Horizontal mattress U-shape suture of the vulvar lips was used as a retention suture (Straiton, 1992).

The owner was advised to daily check the condition of the vulvar lips and to monitor the signs of approaching of lambing. Before lambing, the suture material was removed to avoid hindering of parturition. The ewe gave birth to a live and healthy lamb about 3 weeks after the treatment of the CVP.

\section{Discussion}

This study fully reported a case of pregnant ewe suffered from prepartum complete CVP in a desert area and fully described its successful treatment and follow up. This study reported a case of 
CVP with an approximate diameter of 10.5 $\mathrm{cm}$. It was previously reported that the diameter of the CVP varies from 8 up to 20 $\mathrm{cm}$ depending on the condition and the duration of the disorder (Scott, 2017). The CVP, such as in this reported case, may not be considered directly as an emergency case or life threating. However, in the field conditions, many farmers/owners only present the cases suffered from CVP for treatment by a veterinarian when their trials for correction have failed or sever complications occurred. Due to these circumstances, the prolapsed part becomes more swollen, congested, and dry. Moreover, it becomes more susceptible to injury and rupture (Hosie, 1989). A rupture of the vaginal wall with evisceration of the intestines, bladder or even uterus therefore also associated as severe complications of untreated CVP (Veeraiah and Srinivas, 2010). Another complication that requires an urgent interference is the containment of the urinary bladder in the CVP, this kind of displacement leads to obstruction of the urethra that may cause urinary bladder over-distension and subsequently rupture (Noakes et al., 2009, Pugh, 2002).

Immediate treatment of the CVP is critical as the prognosis is greatly enhanced in case of early interference using the appropriate treatment. There are a lot of alternative methods for the treatment of the CVP in ewe (Kuijlaars, 2011). All these alternative methods are symptomatic with the main aim of preventing the reoccurrence (Sobiraj, 1990). This study fully reported the successful treatment of the CVP in a pregnant ewe. In a recently published study, Thangamani et al., (2018) described 10 "R" principles for treatment of genital prolapses in domestic animals especially cow and ewe. These 10 " $R$ " principles included remove the dirt, rinse the CVP with mild antiseptic, relieve the urine from the bladder, restrain the ewe by epidural analgesia, reduction of oedema using astringent, reposition of the CVP, retention suture, reduce the feed for few days to avoid rumen distension, reduce the roughage to avoid constipation, and remove the suture material before lambing. These 10 " $R$ " principles agreed with these used in this study.

Cervico-vaginal prolapses are highly repeatable, about $35-40 \%$ of ewes who have had CVP before, have them in their subsequent pregnancies. Therefore, it is recommended to identify the ewe that showed CVP in order to be excluded from further breeding.

\section{Conclusion}

Cervico-vaginal prolapse is one of the most common pregnancy disorders in ewes. It may also affect non-pregnant ewes as a postpartum disorder, as well. Using an immediate and appropriate treatment is critical to minimize/avoid further complications of the CVP that may threat the life of the affected ewe.

\section{Ethical standards}

This work was approved by the Animal Ethics Committee of the South Valley University for Veterinary Research, Qena, Egypt. The use and care of the animal, used in this study, comply with the Egyptian animal welfare laws and policies.

\section{Conflict of Interest statement}

None declared by the author with respect to the research, authorship, and/or publication of this article. This study did not receive any specific grant from funding agencies in the public, commercial, or nonprofit sectors. 


\section{Funding}

The author received no financial support for the research, and/or publication of this article.

\section{References}

Adams NR (1990). Permanent infertility in ewes exposed to plant oestrogens. Australian Veterinary Journal, 67: 197.

Alan M, Cetin Y, Sendag S, Eski F (2007). True vaginal prolapse in a bitch. Animal Reproduction Science, 100 (4): 411-414. [PubMed: 17123756]

Anya KO, Nnaji TO, Udegbunam SO (2006). Cervico-vaginal and rectal prolapse in two West African Dwarf (Wad) goats in Nsukka, Nigeria. Nigerian Veterinary Journal, 27 (3): 105-108.

Bristol FM, Djurickovic S (1971). Hyperestrogenism in female swine as the result of feeding mouldy corn.Canadian Veterinary Journal, 12 (6): 132-135. [PubMed: 5104356]

Couri BM, Lenis AT, Borazjani A, Paraiso MFR, Damaser MS (2012). Animal models of female pelvic organ prolapse: lessons learned. Expert Review of Obstetrics and Gynecology, 7 (3): 249-260. doi:10.1586/eog.12.24.

Cox JE (1987). Surgery of the Reproductive Tract in Large Animals. $3^{\text {rd }}$ edition Pub. J.E.Cox,Liverpool University Press, England p1-208.

Dhillon KS, Singh BB, Kumar H, Bal MS, Singh J (2006). Treatment of vaginal prolapse in cows and buffaloes. Veterinary Records, 158 (9): 312. [PubMed: 16517831]
Drost M (2007). Complications during gestation in the cow. Theriogenology, 68: 487-491.

Edgar DG (1952). Vaginal eversion in the pregnant ewe. Veterinary Record, 64: 852 .

Fielden ED (1980). Vaginal Prolapse. In: Current Therapy in Theriogenology. Ed. D.A.Morrow, Pub. W.B. Saunders and Co., Philadelphia, U.S.A. p914

Fisher V (2016). Step-by-step guide to dealing with vaginal prolapse in sheep. Farmers weekly. Retrieved from

https://www.fwi.co.uk/livestock/hus bandry/livestock-lambing/step-stepguide-dealing-vaginal-prolapsesheep.

Gitao C, Akabwai D (1989). Vaginal prolapse in a camel. Veterinary Record 124, 203-204. http://dx.doi.org/10.1136/vr.124.8.2 03.

Gouletsou PG, Galatos AD, Apostolidis K, Sideri AI (2009). Vaginal fold prolapse during the last third of pregnancy, followed by normal parturition, in a bitch. Animal Reproduction Science, 112 (3-4): 371-376.

https://doi.org/10.1016/j.anireprosci. 2008.04.032

Hosie B (1989). Vaginal prolapse and rupture in sheep. In Practice, 11 (5): $215-218$

Hosie B (1993). Treatment of vaginal prolapse in ewes. In Practice, 15: 10-11.

http://dx.doi.org/10.1136/inpract.15. 1.10 
Jackson R1, Hilson RP, Roe AR, Perkins N, Heuer C, West DM (2014). Epidemiology of vaginal prolapse in mixed-age ewes in New Zealand. New Zealand Veterinary Journal, 62 (6): 328-337. doi: 10.1080/00480169.2014.925788.

Kahn C (2005). Merck veterinary manual. $9^{\text {th }}$ ed. Rahway, NJ: Merck, 2005.

Kamalakar G, Jyothi K, Rambabu K, Kumar VP (2017). Management of dystocia with cervico-vaginal prolapse in a non-descript doe. Journal of Livestock Science, 8: 134-136.

Kennedy GF (2013). Prolapse vagina and/or uterus. Ask-a-Vet Sheep. Retrieved from https://askavetsheep.wordpress.com/ 2013/02/02/prolapse/

Kloss S, Wehrend A, Failing K, Bostedt H (2002). Investigations about kind and frequency of mechanical dystocia in ewes with special regard to the vaginal prolapse ante partum. Berliner und Münchener tierärztliche Wochenschrift (Full article in German with English abstract), 115(7-8): 247-251.

Knottenbelt DC (1989). Cervico-vaginal prolapse in the preparturient ewe: An epidemiological and clinical study. Doctor of Veterinary Surgery Thesis. University of Edinburgh, Scotland, United Kingdom.

Kuijlaars M (2011). The occurrence of vaginal prolapse in sheep and cattle. Master Thesis. Department of Obstetrics and Reproduction, Faculty Of Veterinary Medicine, Ghent University.

Kumar A, Saxena A, Anand M, Girjesh Upmanyu G (2018). Genital prolapse in bovine and its management. International Journal of Science, Environment and Technology, 7 (4): 1435-1439.

Lakde MB, Markandeya NM, Sanap NA, Chaudhari RJ (2014). Comparative evaluation of techniques for management of cervico-vaginal prolapse in ante-partum buffaloes. Intas Polivet Journal, 15 (2): 456458.

Low JC, Sutherland HK (1987). A census of the prevalence of vaginal prolapse in sheep flocks in the Borders region of Scotland. Veterinary Record, 120 (24): 571575. [PubMed: 3617413] http://dx.doi.org/10.1136/vr.120.24. 571.

Makhdoomi DM, Bhattacharyya HK, Tufani NA (2010). Clinical management of pre and post-partum prolapse in small ruminants using a modified vulvar suture. Egyptian Journal of Sheep \& Goat Sciences, 5 (2): 63-67.

McKelvey KA, Beachler TM, Ferris KK, Diaw M, Vasgaard JM, Bailey CS (2015). Vaginal prolapse in a pregnant Maine coon cat: a case report. Journal of Small Animal Practice, 56: 473-475. DOI: 10.1111/jsap.12310.

McLean JW (1956). Vaginal prolapse in sheep. New Zealand Veterinary Journal, 4 (2): 38-55.

Miesner MD, Anderson DE (2008). Management of uterine and vaginal prolapse in the bovine. Veterinary Clinics North America Food Animal Practice, 24 (2): 409-419. [PubMed: 18471579] 
Noakes DE, Parkinson TJ, England GCW (2009). Prolapse of the Cervix and Vagina. In: Veterinary Reproduction and Obstetrics. 9th Edition, Saunders Elsevier Ltd. Pub. Balliere Tindall. England Part 2 Chapter 5: 146-153.

Onyango CS, Okello W, Anzuino J, Obiero D (2009). The Donkey Health and Welfare Manual. In: The Donkey Sanctuary Kenya. Kenya General Edition.

http://www.thedonkeysanctuarykeny a.org/downloads_all/DONKEY_MA NUAL_FOR_ANIMAL_HEALTH_ PROVIDERS.pdf

Praveen S, Jayakumar C, Aravind A, Abhilash RS (2016). True prolapse of gravid uterus, bladder and intestines through vaginal tear in a goat. Indian Journal of Animal Reproduction, 37 (1): 63-64.

Pugh DG (2002). Theriogenology of Sheep and Goats. In: Schrefer J. A. (editor) Sheep and Goat Medicine. first edition, Saunders, Philadelphia, USA, p. 173.

Riera FL, Hinrichs K, Hunt PR, Kenney RM (1989). Cervical hyperplasia with prolapse in a mare. Journal of American Veterinary Medicine Association, 195 (10): 1393-1394. [PubMed: 2584103].

Schaefers-Okkens AC (2001). Vaginal Edema and Vaginal Fold Prolapse in the Bitch, Including Surgical Management. In: Recent Advances in Small Animal Reproduction, P. W. Concannon, G. England and J. Verstegen (Eds.) Publisher: International Veterinary Information Service (www.ivis.org), Ithaca, New York, USA.
Scott P (1996). Caudal analgesia in sheep. In Practice, 18: 383-384.

Scott P (2017). Lambing Part 3 Vaginal and Uterine Prolapse: Vaginal prolapse. NADIS Animal Health Skills. Retrieved from http://www.nadis.org.uk/disease-az/sheep/lambing/lambing-part-3vaginal-and-uterine-prolapse/

Scott P, Gessert M (1998). Management of ovine vaginal prolapse. In Practice, 20 (1): 28-34.

Scott P.R., Sargison N.D., Penny C.D., and Strachan W.D. (1995). The use of combined xylazine and lignocaine epidural injection in ewes with vaginal or uterine prolapses. Theriogenology, 43: 1175-1178.

Singla VK, Ahuja AK, Sobti D, Gupta N (2016). Management of cervicovaginal prolapse in a bitch: A case report. Haryana Veterinary Journal, 55 (2): 241-242.

Sobiraj A (1990). Ante partum vaginal prolapse in sheep - an unsolved problem. Tierarztl. Prax (Full article in German with English abstract), 18 (1): 9-12. [PubMed: 2183394]

Straiton EC (1992). Prolapse of the Cervix. The TV Vet. Sheep Book. 6th Edition. Pub. The Farming Press Books and Videos Ltd., Ipswich, Suffolk, England, p1-192. ISBN 10: 0852362129 1SBN 13: 9780852362129.

Thangamani A, Srinivas M, Prasad BC (2018). A comprehensive overview on genital prolapse in domestic animals. Research \& Reviews: Journal of Veterinary Science and Technology, 7 (2): 1-4. 
Van HH, Hesp AP, Versluis A, Zwart P, Van Zutphen LF (1989). Prolapsus vaginae in the IIIVO/JU rabbit. Laboratory Animals, 23 (4): 333336. [PubMed: 2530397]

Veeraiah G., Srinivas M. (2010). Spontaneous extrusion of the intestines and uterus as a squeal to vaginal prolapse in a buffalo heifer: a case report. Buffalo Bulletin, 29 (1): 60-64.

Watts RE (1954). Preparturient Prolapse of the Vaginal Wall. Procedings of the American Veterinary Medical Association, 91st Annual Meeting. p382.

Webster's Third International Dictionary (2000). Ed. A.Merriam-Webster,
Pub. G \& CMerriam Co., Massachusetts, U.S.A.

Wolfe DF (2009). Medical and surgical management of vaginal prolapse in cattle. Presentation " 81 st western veterinary conference”, Auburn.

Zacharin RF (1969). Genital prolapse in ruminants. Australian and New Zealand Journal of Obstetrics and Gynecology, 9 (4): 236-239. [PubMed: 5264836]

Zayed MN, Mahmoud EE, Khalil AM, Salah M, Moustafa MA, Saleh MY, Hassaneen AS (Unpublished data). Lumbosacral injection of lidocaine, detomidine and lidocainedetomidine in goats: Antinociceptive effects and changes on haematobiochemical parameters. 